\title{
THE LARGE AIMEIVAS OF THE PUERTO RICO REGION WITH ONE NEW SPECIES
}

\author{
Chapman Grant, Major, United States Army.
}

The Ameivas of Puerto Rico and the adjacent islands and keys have a general superficial resemblance. The fact that most species are hatched with definite markings which change greatly with growth, going through several phases or combinations of colors and markings, makes it necessary to have fairly large series to determine specific values. Evidently earlier writers have not had sufficient series or the following interesting facts would have come to their attention.

Beginning on Mona, there is a gray species, A. alboguttata, which retains its small dorsal dots through life and has a low number of femoral pores and indistinct or no dorsolateral lines, which if present begin at the neck. Next east lies Puerto Rico, with a brown species, A. exsul, which loses its dorsal dots with age, has a higher number of femoral pores and distinct dorsolateral white lines beginning at the eye. This line fades or disappears with age. On Diablo Island, or key, further to the east, there is a black species with bright blue ventral coloration and side marking, A. birdorum, which retains its large dorsal dots through life and has a low number of femoral pores like the form on Mona. Its dorsolateral white lines fade or disappear early in life. There are other constant and minor differences which the following tables help to bring out:

\begin{tabular}{|c|c|c|c|c|c|c|c|c|c|}
\hline \multirow[b]{2}{*}{ Number of pores } & \multicolumn{9}{|c|}{ Number of femoral pores expressed in per cent } \\
\hline & 11 & 12 & 13 & 14 & 15 & 16 & 17 & 18 & \\
\hline A. alboguttata................ & 1 & 10 & 37 & 38 & 14 & 0 & 0 & 0 & \\
\hline A. birdorum................. & 0 & 18 & 21 & 31 & 27 & 1 & 0 & 0 & : \\
\hline A. exsul.................... & 0 & 1 & 5 & 17 & 29 & 28 & 12 & 5 & 8 \\
\hline
\end{tabular}

The above table separates the Mona and Diablo forms into one group of low pore counts, contrasted with the Puerto Rico form, with a high pore count. The same table expressed in numbers of femora bearing a specified number of pores brings out the same fact. 
158 THE JOURNAL OF THE DEPARTMENT OF AGRICULTURE OF P. R.

\begin{tabular}{|c|c|c|c|c|c|c|c|c|c|}
\hline \multirow[b]{2}{*}{ Number of pores } & \multicolumn{9}{|c|}{ Number of legs having 11 to 19 pores } \\
\hline & 11 & 12 & 13 & 14 & 15 & 16 & 17 & 18 & 19 \\
\hline A. alboguttata - legs $117 \ldots$ & 2 & 12 & 44 & 45 & 14 & 0 & 0 & 0 & 0 \\
\hline A. birdorum-legs $80 . . .$. & 0 & 15 & 17 & 25 & 22 & 1 & 0 & 0 & 0 \\
\hline A. cxsul-legs $310 \ldots \ldots . .$. & 0 & 3 & 15 & 46 & 88 & 86 & 49 & 21 & \\
\hline
\end{tabular}

The following table brings out specific color and pattern differences and serves better than a key.

\begin{tabular}{|c|c|c|c|}
\hline Ameiva & A. alboguttata & A. birdorum & A. crsul \\
\hline 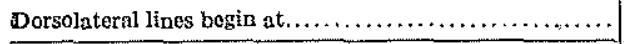 & Shoulder...... & Ear. ......... & eye \\
\hline Dorsolateral lines sometimes absent in young............. & Yes............ & No.......... & No \\
\hline Dorsolateral lines eleareat in young.$\ldots \ldots \ldots \ldots \ldots \ldots \ldots$ & No............. & Yos.......... & Yes \\
\hline Qeneral color of back $\ldots \ldots \ldots \ldots \ldots \ldots \ldots \ldots \ldots \ldots \ldots \ldots$ & Gray............ & Black........ & Brown \\
\hline 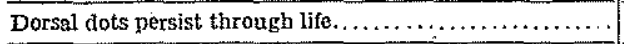 & Yes............ & Yes........... & No \\
\hline 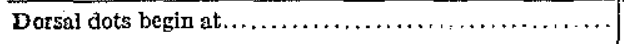 & Neck............ & Shoulder.... & Shoulder \\
\hline 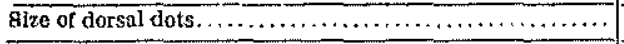 & Small.......... & Large.......... & Very small \\
\hline 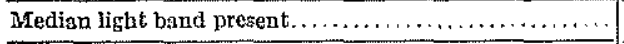 & Seldom........ & No............ & Yes \\
\hline Median light band if present commences at $\ldots \ldots \ldots \ldots$ & Shoulder...... & No........... & Fead \\
\hline $\begin{array}{l}\text { Blnck bands central to dorsolnteral lines present at least } \\
\text { in young }\end{array}$ & 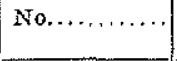 & $\begin{array}{l}\text { Entire back } \\
\text { black }\end{array}$ & Xes \\
\hline 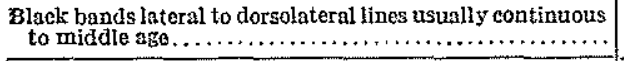 & Yes............. & Yes........... & No \\
\hline 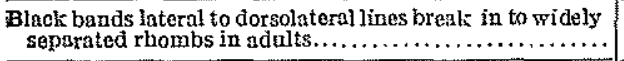 & No............. & No........... & Yes \\
\hline Sateral dots tond to form vertical stripes $\ldots \ldots \ldots \ldots \ldots \ldots$ & No.............. & Yes............ & Yes \\
\hline 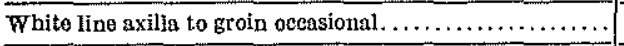 & Xes............. & No........... & Yes \\
\hline 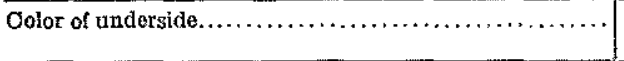 & $\begin{array}{l}\text { White or } \\
\text { light blue }\end{array}$ & Dark blue... & $\begin{array}{l}\text { White or } \\
\text { light blue }\end{array}$ \\
\hline Color of chin of large specimens. $\ldots \ldots \ldots \ldots \ldots \ldots \ldots \ldots$ & Red........... & Purple........ & Lavendar \\
\hline Usual number of anal plates........................... & $5 \ldots \ldots \ldots \ldots \ldots$ & $3 \ldots \ldots \ldots \ldots$ & 3 \\
\hline 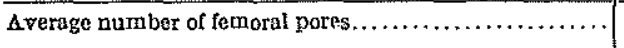 & $13,2 \ldots \ldots \ldots \ldots$ & $13.8 \ldots \ldots \ldots$ & 15.3 \\
\hline
\end{tabular}

Stejneger (1904) gives an excellent description of $A$. exsul and A. alboguttata. His pore counts tabulated are as follows, according to percentages:

\begin{tabular}{|c|c|c|c|c|c|c|c|}
\hline Pores & 12 & 13 & 14 & 15 & 16 & 17 & 18 \\
\hline A. alboguttata, $16 \mathrm{sp} . .$. & \multicolumn{3}{|c|}{81} & 19 & 0 & 0 & 0 \\
\hline A. exsul, $67 \mathrm{sp} \ldots$. & 5 & 1 & 12 & 37 & 27 & 12 & 0 \\
\hline
\end{tabular}


This is interesting as it gives practically an identical distribution found in my larger series. He states, "The main differences (between $A$. exsul and A. alboguttata) seems to be one of coloration". He gives a minute color description but his series from Mona was not sufficient for him to detect specific differences in markings. He points out that $A$. alboguttata has five anal plates but his material was not sufficient for him to speak with finality.

Schmidt (1928) states: "A. alboguttata is extremely close to $A$. exsul, but may be distinguished by the more spotted dorsum. The femoral pores in 40 specimens average 13.2 , in $40 \mathrm{~A}$. exsul, the average is $15.3 . . . "$

His figure, "35 A. alboguttata A.M.N.H. 14003", is misleading. In fact, it could be identified as a specimen of A. oxsul. In my 60 specimens of $A$. alboguttata, not one has the dorsolateral line beginning on the superciliary ridge or has these lines clear-cut. Not one has a median light stripe showing on the neek, and extremely few have any indication of a light stripe, even on the back. Not one has the same color below as above the dorsolateral line. All have black below it. These features in his illustration are all specifically absent in A. alboguttata and specifically present in other species, except the absence of the black line below the dorsolateral white line, which is present in all of my total series of 341 specimens of this group of the genus taken from some of the Virgin Islands and keys as well as the Puerto Rico region.

Consolidating the averages of the pore counts, we have:

\begin{tabular}{|c|c|c|c|c|c|}
\hline \multirow[b]{2}{*}{ Stejneger $\ldots \ldots \ldots \ldots \ldots \ldots \ldots \ldots \ldots$} & \multicolumn{2}{|c|}{ A. alboguttata } & \multicolumn{2}{|c|}{ A. ersul } & A. birdorum \\
\hline & $16 \mathrm{sp}$. & 13.3 & (i7 sp. & 15.4 & \\
\hline Schmidt............................... & $40 \mathrm{sp}$ & 13.2 & $40 \mathrm{sp}$. & 15.3 & $\ldots \ldots \ldots \ldots \ldots \ldots$ \\
\hline Grant.......... & $60 \mathrm{sp}$. & 13.3 & $157 \mathrm{sp}$. & 15.3 & $43 \mathrm{sp}$ \\
\hline Total & $116 \mathrm{sp}$. & 13.2 & $2 n+\mathrm{sp}$. & 15.3 & $43 \mathrm{sp}$ \\
\hline
\end{tabular}

Barbour, in Zoologiea, 1930, Vol. XI No. 4, p. 102, gives the distribution of $A$. exsul as follows: "St.. Thomas, Water Island, St. John, Vieques, Anguilla, St. Croix, and Puerto Rico. Now exterminated on St. Thomas. I have always doubted the St. Croiz record." To this list may be added: all islets around Puerto Rico and Culebra. It is very scarce on Vieques. In the Virgin Islands: Numerous on St. Thomas; strangely not seen on Buck Island of St. Thomas, or on St. Croix or Buck Island of St. Croix; on St. John taken only at Crum Bay; taken on St. James and Little St. James, but not seen on Dog Island, or Congo Key. Taken on Lovango key. West records it on St. Croix in 1793. 


\section{Ameiva birdorum, sp. nov.}

Type:-From Diablo key off Fajardo, Puerto Rico, collected by Chapman Grant, January 21, 1932. Chapman Grant collection, No. 4073, adult.

Range:-Known only from type locality. Diablo key is 'only about ten acres in extent.

Diagnosis :-Distinguished from other Ameivas of the Puerto Rico region by its black back, blue undersides and low femoral pore count, averaging 13.8 .

Description of Type:--Squamation similar to A. alboguttata, almost black above, save neck and shoulders, which are deep olive brown; spotted coarsely from behind shoulders nearly to end of tail with yellowish spots covering about 20 granules. Forelegs black, hind legs black, spotted with yellow and blue. No trace of dorsolateral lines. Sides jet black sparsely spotted with coarse blue dots, spaced in vertical rows as continuation of about every third row of abdominal scales. Underside: Chin purple, creases of neck flesh color; chest and 4 central rows of abdominal scales clear blue, thence laterally alternating black and blue. Vent and stripe on ventral side of fore and hind legs flesh color. Tail like belly but deep blue. Soles of feet dark.

Variations:- A recently regenerated tail is striped longitudinally. The young bear the dorsolateral white lines, which disappear early. A specimen of $60 \mathrm{~mm}$. snout to vent has a remnant of stripes from vicinity of ears to sacrum. At $80 \mathrm{~mm}$. the stripe is practically invisible. The coloration and markings are very constant as in $A$. alboguttata.

Measurement of type in $\mathrm{mm}$.

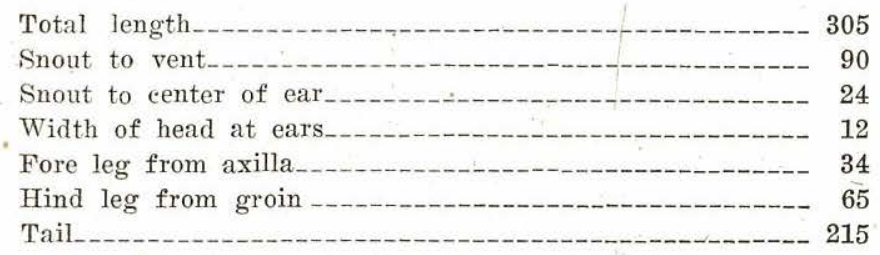

Remarks: The species is numerous. No specimens larger than the type were seen.

Specimens taken: 43.

Named in honor of the family of Bird of Fajardo. Their courtesy and hospitality have done much toward developing the scientific knowledge of northeastern Puerto Rico and the Cordillera keys. 